\title{
Political Economy of Fiscal Policy in Pakistan
}

\section{Abdul Mateen Khan*}

\section{Introduction}

In an underdeveloped country, the state regulates not only the short- term performance of the economy but also its path of development. Such an overwhelming role of the state derives its justification from the very nature of underdevelopment itself. Economics and economists are usually concerned with policy, with a view to determining as to what policies are appropriate in a given economic situation to attain policy objectives such as economic growth, full employment, price stability, redistribution of income and wealth. But adopted policies are often not the policies that economists recommend as the best or even the second best.

It is generally observed that vested interests and pressure groups compete for a greater share in the resources and only those policies have to be put into practice in a society which are adopted by all or a significant majority. The basis of decision-making is not economic factors alone and the influence of non-economic factors has been found more important in terms of compromising the interest of transparency as well as the system in almost all developing countries as against the developed countries ${ }^{1}$. Pakistan is no exception.

The political economy of fiscal policy is generally studied in three stages. (1) Analysis of the economic situation and prescription of policies: (2) The process of decision-making: (3) Implementation of policies: The first stage is the economic one. The second and third stages are more relevant in analysing the problem of policy-making and if one is to see (1) who participates in the decision-making and (2) how much freedom is allowed in decision-making. It explains the weaknesses and strength of the given policy.

This paper investigates the political and economic factors that affect decision-making and the implementation of fiscal policies in Pakistan and not the policy itself. After the introduction, Part 2 discusses the theoretical framework of the dimension of policy-making. Part 3 illustrates various

\footnotetext{
* Director, Foreign Service Academy, Islamabad.

${ }^{1}$ See. Schinichi Ichimura, 'A Conceptual Framework for the Political Economy of Policy Making' in The Political Economy of Fiscal Economy, Ed. Mignal Urutia, UN University, 1989.
} 
aspects of fiscal policy making in Pakistan. Subsequently, the measures taken by the military regime, which took over the government in 1999, are discussed as a case study in Part 4. Various sources for the study include Annual Economic Surveys of Pakistan, which provide sufficient data and details of the policies adopted by the government and their effectiveness, research work undertaken in this and the relevant field papers, published articles and comments.

\section{Dimensions of Policy Making}

Despite the triumph of capitalism and the general acceptance of liberal economic principles, in real society there is no perfect freedom to choose in many decisions. In the present day nation state system, there are many government regulations, and one often needs the government's permission to undertake economic activities ${ }^{2}$. Ichimura (1989) provides a framework with which to analyse decision-making within available environments ranging from one extreme case of control to the other end, that is total freedom.

\section{Fig. 1. Dimensions of Political Aspects of Policy-making.}

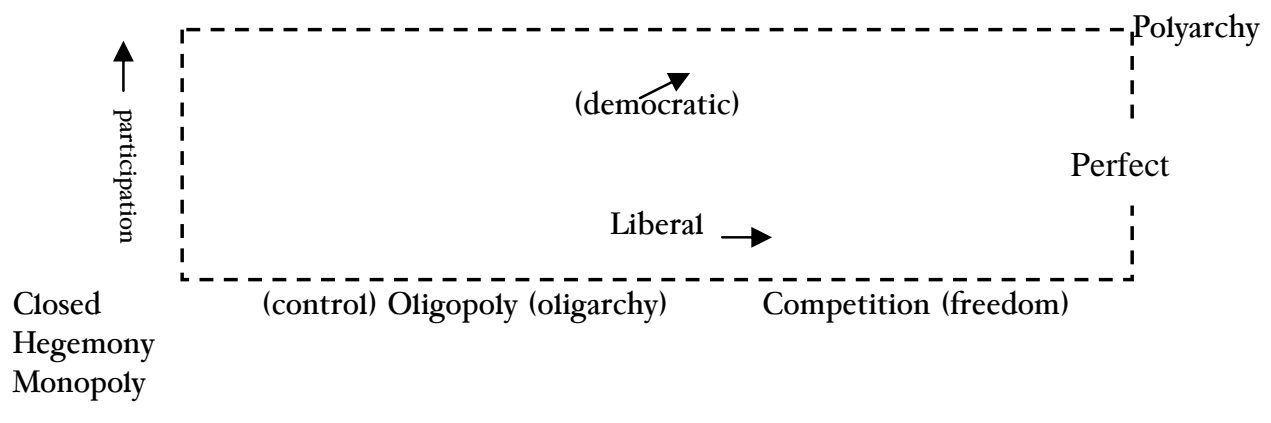

Source: Ichimura (1989)

As indicated in Fig. 1, in relation to the market mechanism, the most hegemonistic form of decision-making is the case of monopoly, whereas the most liberal one is that of free competition. In between there is oligopoly, or workable competition. In this context industrial organisation in each national economy is very important. A distinction between centralised decision-making and decentralised decision-making is an important aspect of political decision-

\footnotetext{
2 See. M. Olsen, 'The Principles of Fiscal Equivalence', American Economic Review, Proceedings, vol 59, no. 2, May 1969, pp:479-489.
} 
making, and it can be applied to economic decision-making as well. Oligarchy is a style of decision-making that falls in between and is most relevant for this paper's analysis, since it is observed that the process is a function of many groups working for or against each other's interests.

\section{The Structure of the Economy and Fiscal Policies}

A national economy has a certain structure, unchangeable in the short run. Many short-term fiscal and other policies must be implemented within the structure as given ${ }^{3}$. It could embrace many things, such as industrial composition, trade relations with foreign countries, economic laws and regulations, institutions, etc. An understanding of the interdependent relations among various economic variables or economic entities is essential in policy analysis and their behaviour that compares with that afforded by an econometric model ${ }^{4}$. This inter-dependence includes international as well as domestic relations. Typically, a short-term objective is price stabilisation, a medium term objective is to reduce unemployment, and a long-term objective is to attain a high per capita income with national security ${ }^{5}$. In this context attention must be paid not only to the effects of policies vis-à-vis the objectives but also the speed with which the effects are realised ${ }^{6}$.

${ }^{3}$ See. M.C. McGuire, 'Group Segregation and Optimal Jurisdictions'. Journal of Political Economy, vol.82, no 1 Jan.1974, pp:112-132.

${ }^{4}$ See. Charles L. Cochern \& Eloise E. Malone, Public Policy, McGraw Hill, 1995. pp; 24-25, \& 83-4

${ }^{5}$ In the study of the political economy of fiscal policy in contemporary LDCs, (less developed countries) it is important to identify the officially stated objectives of each nation's policies in their time horizons and to examine the extent to which they are attained in practice. There are mutual relations among those short, medium, and long-term objectives. Usually, the short term objectives are intended to prepare the national economy for certain expected circumstances and to avoid undesirable consequences while satisfying the medium term objectives. The medium term objectives are, in turn, derived from the long-term objectives with a view to considering the domestic and international situations likely to bear on the economy in the near future. The long-term objectives are determined in close connection with the political objectives of nation building, particularly in developing countries. All the objectives have greater or lesser political implications, but the longer the periods of relevance, the more political the implications of the objectives of economic policies are likely to become.

${ }^{6}$ For the political impacts are often related not just to the effects but the time allowed for the opponents or the affected to adjust themselves to the effects. Policies must be chosen in favour of attaining the long-term objectives rather than the short or medium term objectives if a final choice has to be made. It is highly desirable, therefore, to carefully analyse the interrelations between various policy measures and the three levels of objectives. For this purpose the structure of a national economy must be clearly understood relative not only to its own characteristics but also to its international linkages. 


\section{Process of Decision-making}

The decision-making process is a variation of two extreme cases. Decision-making controlled by a single individual or a group of individuals may be called dictatorial. Or decisions may be called liberal decisions when decisions are made through the democratic process. This may be to some extent closer to the developed world. Generally speaking, decision-making on important policies in any market economy has five major participants. (1) Bureaucrats, (2) political parties, (3) pressure or special interest groups (4) government ministers and $(5)$ the head of state.

\section{Fiscal Policy Making and Pakistan}

\section{A. Historical Background}

The Islamic Republic of Pakistan established in 1947, carried deeprooted traits of a long imperial past combined with diverse traditions of different cultures. The areas which constituted Pakistan were the most underdeveloped regions of British India 7-Superscript. The country had limited infrastructure, feudal control in agriculture and scant industries while lack of decision-making at the political level was important. The worsening economic situation in the late $50 \mathrm{~s}$ also played a very important role in the military intervention of 1958. The military regime believed that the economic difficulties were the result of uncoordinated economic decisions of former governments and decided to put "planning" at the core of fiscal decision making. The result was the formalisation of the Planning Commission as the controlling body for economic development, entrusted with advising governments in their economic decision-making.

Hussain (1999:i) has noted that in the 50's and 60's wisdom was that the state through a strong interventionist and directive role, using the instruments of central planning and big push, and state led industrialisation, would break the low level equilibrium trap of underdevelopment. The 'reformation role', 'authoritarian mode', of the military government remained the basic framework of the economic system of the country until 1971. Though Saeed (1996) lists some taxation measures during the 1958-69 period, except for a few tax reforms and stringent expenditure policies of 1967, no major fiscal legislation was undertaken during this period.

The separation of East Pakistan and subsequent expansion of the administrative machinery proved the prevalent fiscal administration as

\footnotetext{
${ }^{7}$ Ansari, Javed Akhtar, 'Macro Economic Management: An Alternative Perspective’ in Fifty Years of Pakistan’s Economy, ed. Shahrukh Rafi Khan, Oxford, 2001.
} 
unsuitable for meeting the rising demand. The new Constitution in 1973 included comprehensive measures, however, subject to varied interpretations, necessary measures over the distribution of Power, Fiscal Management and related measures. The Fourth Schedule (Article 70/4) provided a list of functions of the Federal and Provincial Governments on regulations and services.

The period from 1972 - 77 witnessed a major restructuring in the economic system of the country. However, the remedy failed to control economic and social difficulties, indicating that no basic far-reaching transformation of the economic structure was envisaged (Ahmad \& Amjad, 1984). The government in its pursuit of mass popularity, despite being faced with a fiscal deficit, launched ambitious investment programmes. The economy grew in the late seventies and early eighties mainly due to credit expansion policies.

\section{B. Macro Setting}

International economic conditions have witnessed cyclical variations for Pakistan. Pakistan's semi-growth economic system was very sensitive to fluctuations in its foreign trade relations because it depended for domestic production on limited but highly critical import components. Pakistan has always faced severe economic difficulties due to foreign exchange shortages and structural issues that accumulated over time ${ }^{8}$. The reasons for the inception and continuation of a semi-growth economic model - in the sense of a small export volume - are generally attributed to fiscal policy.

Other factors can also be cited for creating a "self-sufficient economy" image among politicians as well as the public at large. One was the entrepreneurial lack of experience in international trade. Though Pakistan's integration in the world economy has been moderately rapid (Hussain, 1999:7), except for a handful of exporters specialising in the trade of a few traditional agricultural commodities, knowledge of Pakistani businessman in this area was almost nil leading to loss of competitiveness. High population growth after the 50 s, inventions to fight deadly disease and relative prosperity, became another critical factor in creating inward looking entrepreneurial behaviour.

Various studies in Pakistan have observed the growing tendencies of tax evasion. Iqbal, Qureshi and Mahmood (1998) investigated the size of the underground economy and the extent of tax evasion. According to their

\footnotetext{
${ }^{8}$ See Parvez Hassan, 1998, pp-264
} 
estimates, the size of the underground economy increased from Rs. 15 billion (20\% of GDP) in 1973 to Rs. 1,115 billion (51\% of GDP) in 1996. Tax evasion consequently increased from Rs. 1.2 billion ( $2 \%$ of GDP) in 1973 to Rs. 153 billion in 1996 (6.9\% of the GDP).

Like many other countries, Pakistan had three possibilities to cover its fiscal and trade deficits: (i) Attract foreign capital investments, (ii) Devaluations, and (iii) Borrowing. Except for two brief periods in the early 60s and early 90s, foreign investment in Pakistan has always been insignificant compared to the country's total investments. Until the 1980s, Pakistan has only reluctantly made use of currency devaluations, though the Pakistani rupee was always overvalued.

The governments mainly relied on borrowing as the only measure of "practical and political value" for easing Pakistan's balance-of-payments difficulties. But because the credibility was less than perfect, loans from international institutions and banking systems, in addition to intergovernmental credits were mostly on a short-term basis and often with higher interest rates. When credibility worsened - as in the 1978-80 and 1992-2000 periods - coupled with limited borrowing possibilities, repayment of these accumulated short-term loans became a real burden on the economy. In short, one could quote Dr. Aqdas Kazmi that the fiscal monoliths seriously hampered the growth rate ${ }^{9}$ and the Seven Sins of Planners compounded it, referring to Mahboobul-Haq's famous theory.

\section{Fiscal Policy and Socio Economic Structure}

While Pakistani fiscal policy was stressing the necessity of rapid industrialisation, it clearly underestimated the importance of changes in the socio-economic structure for a smooth, self-sustaining growth process. It included rapid population increase, disguised and open employment, insufficient infrastructure requirement of rapid industrialisation, and education. The financing of the public sector has always been a major problem. The tax system, despite its basically modern structure, failed to meet the financing requirements of an over-ambitious public investment programme and curb the rising consumption demands of the private sector. Inequality of income distribution remained a trouble point of the development strategy and produced social uneasiness. Although research on income distribution in Pakistan is rather scattered and the methodology used open to debate, all seems to point to a rather unequal income distribution with the Gini co-efficient slightly higher than 0.34 .

\footnotetext{
${ }^{9}$ Kazmi, Aqdas Ali, stated in his lecture on 7 October 2002, at NIPA, Peshawar.
} 


\section{Constraining Factors of Fiscal Decision Making}

\section{Legal Political Factors}

The 1973 Constitution created a mixed economic framework based on (1) private property (2) freedom of contract, (3) freedom to work and (4) freedom to engage in private enterprise and (5) the imposing role of the State sector. It, however, has been observed that the constraints placed on these freedoms were also quite numerous and detailed. (Zaidi, 1999:201). It included equilibrium in the private and public sectors, revenue sharing between federal, provincial and local governments, overlap of fiscal powers, etc.

The federation, which collects almost $96 \%$ of revenue, distributes it between the center and provinces under the NFC award. In 1997, the award was approved under a formula for 5 years and was to be renewed in 2002 . However, political differences remain over the volumes and this continues. According to the recent formula, Rs. 193.5 billion will be distributed as provincial share, out of Rs.465 billion to be called by the center. Therefore, the size to be given to the provinces would depend on the $100 \%$ collection as per target of the federal budget. The targets are hardly ever met, consequently reducing not only the development budget of the center but also of all provinces. The issues remained unsettled until the conclusion of the paper 10 superscript.

\section{Market Structure}

\section{Agriculture}

Despite a gradual decrease in the relative share of agricultural output, this sector maintains a prominent place in the Pakistani economy. It has been observed that there has not been enough production in the sector to have a significant influence on fiscal decision making despite the increasing demand and necessity of implementing agricultural taxes in the country (Kardar, 1987:234). On the other hand the fiscal history of Pakistan clearly indicates that agricultural producers have been a powerful pressure group.

\section{Industry}

Industry has been considered as a central pillar of Pakistan's development strategy over the last fifty years attracting vital priority. The share of the manufacturing sector in the GDP witnessed a remarkable improvement from $7.8 \%$ in 1952 to close to $18 \%$ in 2000 . The sectors has, however, witnessed major governmental interventions through nationalisation,

\footnotetext{
${ }^{10}$ See Dawn and other newspapers dated 25, October, 2002.
} 
privatisation, and regulations. A close inspection of different sub sector in industry shows monopolistic or quasi-monopolistic conditions in textile weaving, cement, fertilisers, automobiles, beverages, pharmaceuticals, detergents etc. A quasi or total monopoly in state enterprises is evident in areas such as electricity (distribution in the state sector with binding agreements with IPP), steel, telecommunications, etc. The Concentration Ratios for industry also indicate that the markets for industrial products are far from being perfect, making it significant enough to affect fiscal policy decisions.

\section{Participants of Fiscal Decision Making}

Ajmal Waheed (2001) considers Presidents, Cabinet, Bureaucracy, Courts, Media, Military, Business elite, and donors as groups which influence policy-making in Pakistan. Ahmad \& Amjad (1984:55) have included labour and students under urban groups, and also include IFIs and lending states as major players affecting the decision-making process. There is however, increasing concern being expressed over the management skills in Pakistan. Saiyed (2001:52) notes that the country is facing management problems of abnormal proportions and various sources were unable to cope with the needs of the modern world.

\section{Politicians}

After independence, the political parties took significant time to mature. The general tendency has been, due of course to the legacy of the colonial administrative system, to join the rulers. The governments, in general, have limited opposition from the politicians for fiscal policy decision making in view of the fact that they are motivated by the goals of gaining and retaining office. Fiscal policies of the government are not necessarily optimal careerboosting strategies for politicians ${ }^{11}$. During democratic regimes in Pakistan, the disputes between the governments and the opposition parties were frequently based on trivialities and conflicts among the members of the same party.

\section{Military}

Pakistan has been ruled by the military for most of the period of its existence. Even for the brief periods when the democratic governments were installed, the military has played the role of a major power broker and had a significant role in decision-making. Ajmal Waheed (2001) considers the military establishment as the most important decision making body. Parvez Hasan (1998:38) provides details on defense spending in Pakistan and

\footnotetext{
${ }^{11}$ See for example in Snyder Richards, 'After Neoliberalism'; The Politics in Mexico, in World Politics, vol.51, 1999.
} 
compares it with regional countries, emphasising its role on the expenditure side. It has, however, been involved in active decision-making and the periods of their control tantamount to authoritarianism.

\section{Bureaucracy}

The institutions, which according to the structure are to play a major role in the fiscal decision-making process are the Ministry of Finance and its subsidiary organizations, the Central Board of Revenue and the Planning Commission. The Ministry of Finance and Planning Commission have some particular characteristics which distinguish them from the bureaucratic state apparatus.

\section{Ministry of Finance (MF)}

The Ministry of Finance has always played an important role in the determination of fiscal policy and it has refrained from openly protecting certain groups in society at the expense of others. It has generally given the image of a responsible body with the primary occupation of protecting the state treasury. Although some radical policy proposals have occasionally been developed by the Ministry, they are essentially bureaucratic inventions born of the daily experiences of the staff rather than bold attempts to create a coherent and sound fiscal policy.

\section{Planning Commission (PC)}

The Planning Commission is a comparably young organisation and does not have a tradition like that of Ministry of Finance. It is generally composed of technical personnel the number of which, however, witnessed a marked increase. The officials are mostly from specialised fields of social sciences and this diversity creates a heterogeneous body comprising people of widely different views and competence. Political inability has also affected the Planning Commission staff more than the Ministry of Finance's bureaucracy resulting in a high turn over rate among the top level. There is a general impression that its views are sacrificed for the political needs of the ruling elite (Ahmad \& Amjad 1984:56). 


\section{Pressure Groups}

\section{Labour}

The ability of labour to influence fiscal decision-making has fluctuated radically depending on the number of organised workers, social legislation, and political conjuncture. In Pakistan, organised unions have been restricted to the industrial sector and state enterprises. Their ability to exert pressure increased after the 1973 Constitution. However, the military take over in 1977, policies of deregulation and privatisation in the 1990s and the military takeover in 1999 have significantly reduced their role as a pressure group.

\section{Business}

The lobbying activities of business circles are realised either through business organisations or informal contacts. Business as a pressure group is considered as a weak and loosely knit organisational structure. Business organisations in Pakistan can be divided into two broad categories. In the first category we find a great number of professional 'Chambers' and 'bourses'. Their presence lessens the strict governmental control over businesses. The most important bodies in this group are The Federation of Chambers of Commerce and Industry, All Pakistan Textile Mills Association, Association of Cement Manufacturers, Association of Sugar Mills, etc. Due to the authoritarian nature of the government, business organisations found it difficult to operate, but their role increases during political governments, with whom they have strong organisational contacts, as against the private contacts with the authoritarian regimes.

\section{Decision Making Process in Pakistan}

In the decision making perspective, Ajmal Waheed (2001) concludes that the policy making process in Pakistan is not yet institutionalised, rather it is 'politicised' and 'bureaucratised' without norms, values and standard procedures for policy formulation. He points out that with the change of government most policies whittle away and fail to realise stated objectives leading to uncertainty in the market. He suggests that policies in Pakistan lack meaning, purpose and sense of direction.

Ahmad \& Amjad (1984:54) on the other hand, view that economic decisions are not taken in a vacuum. In modern western democracies, public opinion pays special attention to fiscal decision-making when it is related to major changes in government revenue and expenditure structure. This type of fiscal decision may produce considerable shifts in the benefits and cost 
distribution of public sector services. However, in underdeveloped countries such as Pakistan, the decisions are highly influenced by the political philosophy of the rulers.

Economic policies were designed for most of the period as an integral component of the formal planning process. The military civilian elite that realised power after the 1958 intervention relied so much on the necessity of long-range economic plans that "planning" was specifically indicated in the 1962 Constitution as a requirement of development policies. Ahmad \& Amjad (1984:57) outline the period of 1956-68 as powerful PC and 1968-77 as decline of PC. Subsequent periods have witnessed a mixed role, but in general, decision making moves away from it. Ansari (1999:73) attributes the diminishing role of PC to the commitments of the governments with the IFIs.

The planning body has been designed as a two-layer organisation in the 1973 Constitution, the Economic Coordination Committee (ECC) of the Cabinet and the Planning Commission. The ECC comprising both politicians from the Center and the Provinces and high-level bureaucrats, has a very peculiar status unparalleled in the public sector. Responsibility of the council is "to assist in the determination of the goals of economic and social policies, and evaluate consistencies of the long term plans and to examine the suitability of proposed policies". The 1973 Constitution empowers the federal government to borrow to finance its budgetary expenditure within such limits as parliament may fix from time to time. When the revenue-expenditure gap widened in the 1980 s at subsequent periods parliament was either non-existent or failed to legislate restrictions on the borrowing.

The parliamentary discussion of the finance bill comprises a process which takes place in the Plenary of the National Assembly in case elected governments are in power. The discussions of the Assembly are more hectic and ineffective. The lobbying activities of the government and the private sector remain shrouded during the parliamentary debates. Debates on the budget do not create for the government the risk of major changes in the finance bill. Parliamentary debates in the multiparty period have almost always furnished occasions for heated political discussions between the government and the opposition parties rather than serving as a mechanism for economic/fiscal control.

Pakistan's fiscal history reveals that governments have often receded before mounting pressures from politically important groups such as the feudals, the industrialists and merchants and the military, and have responded to such pressures by making important modifications in the tax and the public 
expenditure structures ${ }^{12}$. The failure to tax agricultural incomes and asking merchants to record all their transactions, the fiscal manipulations for solving the extreme financial difficulties of some big firms, the large increases in military expenditures in the years following military interventions are all noticeable examples of such pressure-tied fiscal policy decisions.

\section{Other Fiscal Decisions}

Even during the democratic era, separate laws, decree-laws, decrees, and bulletins of the MF, the Treasury, and the Supplementary Revenue Orders (SRO) of the Central Board of Revenue regulate fiscal policy decisions that are not covered in the finance bill. They are prepared under the political guidance of the government by the staff of concerned agencies. The preparations are generally completed behind closed doors, and the public is not given any systematic information.

\section{Fiscal Policy}

\section{Public Sector}

A large public sector made fiscal policy an important determinant of the economy in 1973-95. A clear understanding of the state involvement in economic life necessitates a brief explanation about the public sector. It may be divided into four groups:

\section{Central Government}

This sector has the basic duty of supplying traditional government services. It comprises public agencies, which are classified in the Pakistani budgetary system as administrations under the general budget and administrations with annexed budgets.

\section{Local Government}

This was organised in a three-layer administration: (1) Provincial administrations, (2) Municipalities, and (3) District Councils for villages. A new administrative unit called Development Authorities (metropolitan municipalities) was added to this scheme off and on. Under the new Devolution Plan 2000, the administrative structure is being re-organised at the Provincial and District levels. The system has started functioning but it is too early to

\footnotetext{
${ }^{12}$ See Kaiser Bengali, ‘Contradictory monetary and fiscal policies’, Dawn, October 10, 2002.
} 
analyse its role and effectiveness since many issues, in particular financial ones, remain unclear.

\section{Functionally Decentralised Public Agencies}

The government sector also includes some decentralised public agencies with specific administrative and budgetary authority. The State Bank, the Pakistan Radio and Television Administration and the Scientific Research Institutes can be cited among prominent examples of administration in this category.

\section{State Economic Enterprises}

In the last category of the government sector, there existed about 40 state economic enterprises, which assumed important roles in different areas of the economy. They grew from a handful of small government factories until 1973 to major economic players in the 70s (15) to 90s (105) until the process of privatisation was initiated.

\section{Public Expenditure}

Hafiz Pasha and Mahnaz Fatima (1999) discuss important revenue and expenditure trends in Pakistan. They point out that Pakistan started out with a very low tax ratio (tax revenue/GNP) of less than $4 \%$ due to a small industrial base and scarcity of foreign exchange, which restrained imports. Many tax exemptions were granted in the last fifty years to encourage industrialisation. On the expenditure side the big jumps are in military expenditure, which increased from $3.2 \%$ of GDP in $1949-50$ to $7.7 \%$ in $1989-90$. The other big jump has been in debt service that increased from $0.2 \%$ of GDP to $8.3 \%$ in 1994-95. While the increased expenditure on two components (defense and debt servicing) meant a crowding out of the supportive and maturing role of the state leading to a decline in the share of social, economic and community services, the fiscal set of exemptions and subsidies led to inefficiency and larger deficits. Table 1 provides shares of various sectors to which the expenditure was directed from 1970-2000. 
Table-1: Distribution, Percentage with the Yearly Public Sector Expenditure

\begin{tabular}{lllllll}
\hline $\begin{array}{l}\text { IN \%AGE } \\
\text { OF TAL } \\
\text { YEARS }\end{array}$ & $\begin{array}{l}\text { GDI \% } \\
\text { OF } \\
\text { TOTAL }\end{array}$ & $\begin{array}{l}\text { CONSOLI- } \\
\text { DATED } \\
\text { BUDGET } \\
\text { EXP. \% }\end{array}$ & $\begin{array}{l}\text { DEBT } \\
\text { SERVICING } \\
\text { \% }\end{array}$ & $\begin{array}{l}\text { MIITARY } \\
\text { EXP. }\end{array}$ & $\begin{array}{l}\text { ADMN. } \\
\text { EXP }\end{array}$ & $\begin{array}{l}\text { \% OF } \\
\text { EXPEND- } \\
\text { ITURE IN } \\
\text { GNP }\end{array}$ \\
\hline $1990-91$ & 5.6 & 25.7 & 3.5 & 24.8 & 5.2 & 19.0 \\
$1991-92$ & 7.7 & 26.7 & 4.2 & 23.6 & 5.6 & 20.1 \\
$1992-93$ & 2.3 & 26.2 & 4.7 & 25.0 & 5.8 & 20.7 \\
$1993-94$ & 4.5 & 23.4 & 5.0 & 25.2 & 7.0 & 19.4 \\
$1994-95$ & 5.3 & 22.4 & 4.1 & 24.4 & 8.0 & 18.4 \\
$1995-96$ & 6.8 & 24.4 & 4.9 & 23.1 & 9.2 & 18.8 \\
$1996-97$ & 1.9 & 22.3 & 5.2 & 23.6 & 8.5 & 17.7 \\
$1997-98$ & 4.3 & 23.7 & 6.3 & 21.5 & 9.7 & 17.3 \\
$1998-99$ & 4.2 & 22.0 & 6.0 & 22.1 & 10.3 & 15.6 \\
$1999-00$ & 3.9 & 23.4 & 6.6 & 20.2 & 9.8 & 15.6 \\
$2000-01$ & 2.6 & 21.8 & 5.3 & 20.8 & 13.6 & 14.7 \\
\hline
\end{tabular}

Source: Economic Survey (Pakistan) 2000-01

\section{Public Revenues}

The foundations of the present tax system were present earlier, but were re-enacted in 1973 . The overall elasticity of the tax system remained low during the 1973-95 period. Two explanations could be offered: (1) A pre-established economic and social milieu was necessary for the smooth functioning of the fiscal institutions. Throughout the period, neither had the fiscal administration the capacity of properly applying the tax laws not did the taxpayers the intention and possibility of abiding by their rulers, (2) Large segments of society - e.g. landlords, tribal lords, industrial elite- had a dislike towards being taxpayers. Pressure from groups forced the politically weak governments to broaden exemptions. Table 2 and 3 provide tax revenue collections from 1990-2000 and the relative share of direct and indirect taxes.

Table-2: Relative Weight of Direct Tax \% of GNP

\begin{tabular}{llllll}
\hline Tax form & $\mathbf{7 0}$ & $\mathbf{8 0}$ & $\mathbf{9 0}$ & $\mathbf{9 5}$ & $\mathbf{2 0 0 0}$ \\
\hline Direct & 10 & 16.9 & 12.6 & 24.7 & \\
Indirect & 88.4 & 70.4 & 78.3 & 53.2 & \\
Total Tax & & & & & \\
\hline
\end{tabular}

Source: Economic Survey (Pakistan) 2000 - 01 
Table-3: Percentage of Distributors of Tax Revenue

\begin{tabular}{|c|c|c|c|c|c|c|c|}
\hline & $\begin{array}{l}1990- \\
1991\end{array}$ & $\begin{array}{l}1995- \\
1996\end{array}$ & $\begin{array}{l}1996- \\
1997\end{array}$ & 1997 & $\begin{array}{l}1998- \\
1999\end{array}$ & $\begin{array}{l}1999- \\
2000\end{array}$ & $\begin{array}{l}2000- \\
2001\end{array}$ \\
\hline $\begin{array}{l}\text { Direct } \\
\text { Taxes \& } \\
\text { Property }\end{array}$ & 20.0 & 78 & 85 & 103 & 110 & 112 & 133 \\
\hline $\begin{array}{l}\text { Indirect } \\
\text { Taxes }\end{array}$ & 91.0 & 190 & 197 & 190 & 198 & 234 & 283 \\
\hline Total & 111.0 & 268 & 282 & 293 & 308 & 346 & 401 \\
\hline $\begin{array}{l}\text { \%age of } \\
\text { GDP }\end{array}$ & 11.0 & 13 & 12 & 11 & 10 & 11 & 11.6 \\
\hline
\end{tabular}

Source: Economic Survey (Pakistan) 2000 - 01

Burki (1996:332) points out the narrow tax base system, inelasticity of government revenue and enormous leakages as the main problems of the fiscal system in Pakistan. He suggested the inclusion of accountability in the system along with expanding the tax base, and the imposition of sales tax in the form of value added taxes on all products. Kazmi (1998:1153) called for immediate tax structure reforms and the servicing of entire public sector expenditure. It has since been implemented and has been a major tax revision in the 50 years history of the country. The government of the time (1997) also initiated the rationalisation (enhancement) of the utility charges and ending subsidies in order to reduce fiscal deficits.

\section{Institutional Changes}

The British in the 1937 Act laid the foundations of the basic administrative framework. It was later complemented in Pakistan through the Constitutions of 1956, 1962 and 1973. The main traits of the tax administration and the basic rules concerning public expenditure were kept intact by many regimes. The governments in the $70 \mathrm{~s}$ and 80 s were content with minor amendments to the basic legislation on fiscal institutions, while the economic/fiscal conditions of this period required a complete change. Kardar (1987) states that it was not until 1985 that one could guess the nature of the economic philosophy behind the taxation policies of the government.

\section{General Trends}

The evolution of the Pakistani fiscal system was affected by the economic growth of the country, which brought about a gradual capitalisation and monetisation of the whole economic structure. As to the expenditure side the efforts of the government to shape the public expenditure structure according to its political philosophies were also highly restricted by the demands of the growth 
process. Since the tax system was not elastic enough (Fatima \& Hafeez 1999) to cover the over-ambitious expenditure targets, the public sector bitterly felt an acute financing problem during most of the period. Inefficient management of the state economic enterprises, which coincided with high government subsidies for their products, also created huge financing deficits in this sector. Unable to meet these financing requirements, fiscal decision makers transferred the burden to the Central Bank.

It is observed that for the most part of its history Pakistan had faced oligarchy in decision-making. Kaiser Bengali in his article 'Contradictory Monetary and Fiscal Policies (Dawn, 13, October, 2002) has observed that 'all regimes in Pakistan have justified their takeover' or coming into office 'on the grounds of mismanagement by the erstwhile (previous) governments'. He points out that decisions are based on the explicit or implicit calculus of costs and benefits. Decisions in Pakistan 'are made in favour of those options where those who stand to benefit from an option are different from those who are likely to bear the costs of that option. If those in authority are likely to be beneficiaries, a favourable decision is likely; if they are likely to bear the costs, the option is not likely to be chosen'.

The basic lines of fiscal policy in the 1990s, which seem to reflect the liberal economic ideas of the present government as well, were: decrease in the relative size of the public sector, decline of the ratio of public investment, more current expenditures, decrease in the relative share of tax revenues decrease and increase in public borrowing, decrease in the personal tax burden, decline in the relative share of appropriations for social services, continuation of large budget deficits, gradual decrease in tax evasion possibilities of some social groups, such as merchants, because of the introduction of fiscal measures encouraging individuals to collect invoices and introduction of the value-added tax. It also included increasing use of extra-budgetary funds, preparation of various official and semi-official projects, and growing importance of a restricted body of advisors within the prime ministry and chief executive office on economic/fiscal matters.

\section{Case Study: 1999 Decisions Good Governance and Fiscal Management}

\section{The Circumstances}

Since 1985 the Pakistani economy had been experiencing an interesting policy change of large magnitude. A new growth strategy different in some important respects from the earlier ones seemed to have made its mark on the future development of society. When the revenue expenditure gap increased in the early 1980s, authoritarian governments at 
the time did not apply restrictions on borrowing, rather signed hefty loan deals with the US and IFIs, which were possible in the wake of the Afghanistan crisis. The parliaments established in 1985 and after were elected on non-party system basis and the elected representatives were more sensitive to the voters' reactions to the price increases of utilities, subsidies on food and inflation. The tasks of balancing the budget and price increases were achieved through four caretaker governments between 1988-1997. Deficit financing, however, continued without any bounds and public debt rose in geometrical progression. Debt increased from 60\% of GDP in 1990 to $102 \%$ by the end of 2000 . During the period the external shock was borne by the country in 1998 when the international community applied sanctions after the atomic weapons experiments.

The military takeover of 1999 provided a political framework of autocratic character for restructuring. The political constraints of the government were quite different from those of the pre 1977 and the 90s period as well as those of the military regime between 1977 and 1988. The culmination of different political conditions in a relatively short period for the implementation of the same set of decisions has created a kind of laboratory experiment for the analysis of fiscal decision-making.

\section{Constraints}

The constraints on the decision-making in the 90s were high debt, low revenue, sensitive public opinion to traditional IMF recommendations and even otherwise unbalanced IMF recipes on revenue and expenditure, and the inability of the governments in the 1970 - 1996 period to revise the taxation structure. From October 1999 to October 2001, external factors remained highly negative with the country facing sanctions of various kinds burdening its foreign exchange earnings and lessening the options of foreign borrowing.

\section{Decision Making}

In this process the military government in 1999-2000 had to be content with the cooperation of a limited number of high-level bureaucrats and advisers from the IMF and World Bank. The IMF and the IBRD representatives, who had been in Islamabad since the late 80 s advising the government on all issues in particular on the implementation of structural adjustment programmes, had various contacts with the Ministry of Finance and CBR, along with other government officials during these preparations. However, the government did not admit that the revised measures were basically in line with the IMF recommendations. 


\begin{abstract}
Absence of any political organisation, the general public being disinterested and the total control of the military government over the affairs of the state provided an opportunity to revise the finance bill as and when required during the year. The role of the Planning Commission was enhanced from a dormant body to that of an advisory one in 2000 and many professional economists were brought in to analyse the policies. Recognising the fact that Pakistan's economic problems were structural in nature and the objectives of sustained high growth, low inflation, and external payment viability could not be achieved without removing structural bottlenecks, the government took a series of structural reform measures (Economic Survey 2000-2001).
\end{abstract}

While the external process subsided by the end of 2001, mainly due to a change of the country's foreign policy, the role of donor institutions was enhanced with the finalisation of all agreements with conditionalities. The emphasis of the donors remained for a high share of private investments and the diversion of their loans to the private sector. This strategy of the donors aims at the establishment of more neutral incentives regime that significantly favours exports, capital-intensive industries and heavy enterprises against the small and medium ones ${ }^{13}$. It does not in any way help in curbing the trend of ever increasing poverty in the country.

\title{
The Measures
}

It has long been observed that serious attempts were needed to revamp the loopholes in tax laws, credible deterrence, pre-emptive law, and accountability and expenditure taxation. As listed by the Economic Survey of Pakistan (2000-2001:63), wide scale tax reforms were initiated aimed at broadening the tax base, improving tax compliance, minimising the level of corruption, streamlining the tax laws, and the tax administration. Elimination of whitener schemes, a two tier agricultural income tax and broadening and streamlining the General Sales Tax (GST) were other measures. The tax survey and documentation of the economy were the 'most important elements of the tax reform'.

On fiscal transparency, audit and accounts were separated, ad-hoc public accounts committees were set up and long term restructuring of the CBR was undertaken.

Other economic measures included the improvement of governance, financial sector reforms, trade and tariff reforms, Debt Management Committee and establishment of federal and provincial tax ombudsman.

\footnotetext{
${ }^{13}$ See report in Dawn, p-16, dated 18 October, 2002, by Khaleeq Kiyani.
} 
Under the donor assistance programme, policy and regulatory reforms in areas of tax administration continued ${ }^{14}$. With the new conditions, which the government has already accepted ${ }^{15}$, the fiscal policy would be adjusted to promote long term capital formation by allowing income tax deduction for contribution to the SECP approved annuity schemes of life insurance, on house loans, on bonus shares from listed companies and mortgage markets.

\section{Conclusion}

Fiscal policy has always played a major role in determining economic performance. This role stems from the large share the public sector has in the creation and utilisation of economic resources. The traditionally autocratic and reformist character of the bureaucracy may well be another reason for the high reliance of various governments on centrally planned fiscal policy. Pakistan's experiment in the 1990s suggests that democratic regimes, despite being democratic, did not preclude the possibility for audacious decisions, which authoritarian governments under unfavourable even hostile political conditions can make. They normally have inherited extremely difficult economic situations and there was no quick solution to the problems that have accumulated over decades.

It is also to be noted that the military civil bureaucracy in Pakistan has always carried a self appointed mission in administering the country, the role which probably is a remnant of colonial rule. It is strengthened after the imposition of military rules during which they are the only social forces capable of making efforts for reformation or otherwise. It has maintained its position despite the fact that with the gradual development of society, it is perceived as a deterrent rather than a stimulant of economic modernisation. Recent efforts of the government and the liberalisation policies of the $90 \mathrm{~s}$ under pressure form the IFIs to lessen the role of controlling elements and to reorganise the public sector seem to have only partially changed the situation. The relative financial weakness of businessmen and their old habit of relying on government decisions reduced this pressure group's influence on fiscal decision- makers until recent years. Labour, another potentially powerful pressure group, has also had quite a minor effect on the determination of fiscal policies; the concessions of the government in the 1970 s to excessive pressure from labour groups for more wage increases created a heavy burden on the workings of private and public enterprises.

\footnotetext{
${ }^{14}$ Ashfaque Ahmad, pp.16

${ }^{15}$ See report by Ahtisham Ul Haque, "New Conditionalities Accepted”, Dawn $21^{\text {st }}$ Oct. 2002, P. vi.
} 
As time goes by, it may be noted that the informal decision-making process, which was centered around the prime minister, or chief executive of the country, and the increasing influence of a body of officials and private advisors in this process continues. The gradual increase of the pressure emanating from business on politicians and bureaucrats seems to be a new element, while legislation and the decision-making process in Pakistan have always been a slow process. In this context, it is unimaginable to expect policies which could be termed as favouring the teeming millions of the country.

The 1990s decisions marked the beginning of new economic/fiscal policy strategy. They aim at replacing the decades old closed economic model with a liberal, export oriented one. By 2001, this new policy seems to have reached some of its objectives, although serious socio-economic prices have been paid for them. Some political-economic taboos, such as a fixed exchange rate policy, a severely restricted import regime, and unnecessary government interventions in the price system, etc. have been broken. The price society has to pay for these results are the restrictions an individual rights, high price increases, and deteriorating income distribution ${ }^{16}$.

Current policies suggest that a liberal exchange rate policy could create a major increase in the country's export-end service revenues by diverting internal resources to foreign trade. But significant long run increases necessitate policies far exceeding short-run monetary-fiscal measures. The government is making an all out effort on fundamental restructuring of the economy and the cooperation of major foreign investors ${ }^{17}$ for the continuation of a policy of economic opening and the securing of respectable economic growth. Such a restructuring will obviously take time and require successful management of domestic and international policies. In the meantime, the resulting balance of payments difficulties, price increases, and domestic industrialists' pressure may call for the return of the former import-substitution model and to excessive restrictions on foreign economic relations despite the bindings of W'TO.

Notwithstanding the importance of the subject and the fact that many writers tend to discuss the phenomenon, there still remains a vacuum

${ }^{16}$ Zafar Iqbal and Rizwana Siddiqui investigate the "Impact of Fiscal Adjustments and Income Distribution in Pakistan" in the Pakistan Development Review, vol. 38 No. 1, 1999, PIDE, Islamabad.

${ }^{17}$ Karachi Export Processing Zone, has planned to increase the number of such zones from merely one now to 17 by the next three years. All this would involve massive foreign investments. 
in the development of a political economy model on this issue. However, it can be ascertained from this discussion that the most important requisite for the success of a long-range and effective fiscal policy is the conscious understanding by the politicians and the decision-making bodies of all its requirements. While one observes the negotiations for rescheduling and more loans from donors, the finalisation of some agreements on credit facilities and foreign investments' concessions, the belief in the promises being made for self reliance, prudent expenditure policies and the enhancement of domestic resources, dissipates. It is yet to be observed if the present ruling elite and their partners from politics, in the absence of the right kind of domestic pressure would have a grasp of all the contributing factors for such a policy. 


\section{References}

Ahmad, Viqar and Amjad Rashid, 1995. The Management of Pakistan's Economy 1947-82, Oxford.

Ahmad, Ashfaque, 'The Impact of Uruguay Round on The World Economy', Pakistan Development Review. 33(4), PIDE, Islamabad.

Ansari, Javed Akhtar, 2001. 'Macro Economic Management: An alternative Perspective' in 'Fifty Years of Pakistan's Economy', ed. Shahrukh Rafi Khan, Oxford University Press.

Charles L. Cochern \& Eloise E. Malone, 1995. 'Public Policy', McGraw Hill.

Hasan, Pervez, 1998. "Pakistan's Economy at the Crossroads" Oxford University Press.

Haq, Ehteshamul, Dawn, October 2002.

Hussain, Ishrat, 1999. "Pakistan, the Economy of an Elitist State", Oxford University Press.

Ichimura, Schinichi, 1989. 'A Conceptual Framework for the Political Economy of Policy Making' in The Political Economy of Fiscal Economy, Ed. Migual Urutia, Shinchi Ichumira and Setsuko Yukawa UN University.

Iqbal, Qureshi and Mahmood, 1998. PIDE Study.

Iqba1, Zafar and Siddiqui, Rizwana, "Impact of Fiscal Adjustments and Income Distribution in Pakistan”, Pakistan Development Review, Vol. 38 No. 1, 1999, PIDE, Islamabad.

Jama1, M.S. “Labour Policies: A critical review’ Dawn, 2002. Oct. 13.

Kaiser Bengali, 'Contradictory monetary and fiscal policies', Dawn, 2002. October 10.

Kardar, Shahid, 1987. Political Economy of Pakistan, Progressive Publishers.

Kazmi, Aqdas Ali, "Fiscal Policies of Pakistan", The Pakistan Development Review, Vol. 37, No. 4, 1998, PIDE, Islamabad.

Kiyani, Khaleeq, Report on Investments in Dawn, p-16, dated 18 October 2002. 
McGuire, M. C., 'Group Segregation and Optimal Jurisdictions'. Journal of Political Economy, vol.82, no. 1 Jan.1974.

O1sen, M, 'The Principles of Fiscal Equivalence', American Economic Review, Proceedings, vol 59, no. 2, May 1969.

Saeed, K. Amjad, "Principle of Taxation: Taxation System of Pakistan", Pakistan Journal of Public Administration, January - June, 1996

Saiyed, Aman V. "Pakistan A Crisis of Management" in Pakistan Management Review, Pakistan Institute of Management, Karachi, Second Quarter 2001.

Snyder, Richards, 'After Neo-liberalism; The Politics in Mexico', in World Politics, Vo1.51, 1999.

Waheed, Ajmal, 'Policy Making and implementation in Pakistan', Journal of Rural Development and Administration, Pakistan Academy for Rural Development, Volume.XXXIII, No.2, Peshawar, 2001.

Zaidi, Akbar, S. 1999. Issues in Pakistan's Economy, Oxford University Press. 